\title{
INITIATE STUDY: Insulin versus Oral Hypoglycemic Agent as Initial Therapy for Newly Diagnosed Diabetes Mellitus Type 2: A Systematic Review and Meta-Analysis
}

\author{
Ma. Marylaine Dujunco, ${ }^{1}$ June Hayrelle Gorriceta, ${ }^{1}$ Oliver Allan Dampil, ${ }^{2}$ Roberto Mirasol$^{2}$ \\ ${ }^{1}$ Department of Medicine, St. Luke's Medical Center, Quezon City, Philippines \\ ${ }^{2}$ Section of Endocrinology, Diabetes and Metabolism, Department of Internal Medicine, St. Luke's Medical Center, Quezon City, Philippines
}

\begin{abstract}
Objectives. This study aims to evaluate the effectiveness of initial insulin therapy versus oral hypoglycemic agents in glucose control among newly diagnosed Type 2 diabetes patients.

Methodology. This is a systematic review and meta-analysis of RCTs with quality grade B searched using the medical subject headings (MeSH): diabetes mellitus type 2, insulin, oral hypoglycemic agent, with adults newly diagnosed with type $2 \mathrm{DM}$ as subjects and given insulin ( \pm metformin) vs. OHA. Results were summarized as graphs and forest plots using the random effects due to foreseen sources of heterogeneity using Review Manager version 5.1.

Results. Presence of substantial heterogeneity prevents us from making a conclusion. All four studies showed lower post treatment BMI among participants in the insulin treatment arm. An opposite finding was expected as insulin is known to cause weight gain. Main adverse effect was hypoglycemia.

Conclusion. Among newly diagnosed type 2 DM patients, there is insufficient evidence for or against the use of insulin compared to oral hypoglycemic agents as initial management in terms of improvement in glycemic control, decrease in insulin resistance, and improvement in beta cell function.
\end{abstract}

Keywords: Insulin; Oral hypoglycemic agent; Diabetes mellitus type 2; glycemic control; beta cell function

\section{INTRODUCTION}

Diabetes mellitus has become a worldwide pandemic with an estimated adult prevalence of 382 million in 2013. Prevalence is predicted to rise to around 592 million by 2035. ${ }^{1}$ The disease currently has no known cure, and because of its serious complications, tight sugar control and reduction of glycosylated hemoglobin is important. The initial management of lifestyle modification involving medical nutrition therapy and exercise often is not sufficient to reduce blood glucose levels to acceptable levels. Applying the 2013 American Association of Clinical Endocrinologist (AACE) Comprehensive Diabetes Management Algorithm, the next step after lifestyle will be to use oral hypoglycemic agents; initially, as monotherapy progressing to triple therapy as stratified by the entry $\mathrm{HbA1c}$ level. Insulin enters the algorithm only after failure of triple therapy or when glucose control is very poor, with $\mathrm{HbA} 1 \mathrm{c}>9 \%{ }^{2}$

The rate of progression of $\beta$-cell failure determines the rate of disease progression in Type 2 diabetes. From the time of diagnosis, the $\beta$-cells produce less insulin, and this is believed to be due to the wearing out of the $\beta$-cell after it has been forced to continuously hypersecrete insulinwhich is the mechanism of action of sulfonylureas. ${ }^{3}$

Rarely do physicians start insulin therapy in newly diagnosed stable diabetic patients. Most, if not all, patients would also choose oral hypoglycemic agents over insulin especially at time of diagnosis. In 2011, the ageadjusted percentage of adults with diabetes who reported taking pills only was 3 times higher than those who reported using insulin only (50.3\% vs. $17.8 \%) .{ }^{4}$ However, it has been hypothesized that using oral hypoglycemic agents further pushes pancreatic beta cells to failure. The initial benefits of sulfonylurea agents are caused by increasing insulin secretion from already deteriorating pancreatic beta cells. ${ }^{5}$ Initial insulin therapy can rapidly address the glucose toxicity and improve beta cell function in newly diagnosed type 2 diabetics.6,11 Hence, there are many proponents of initiating therapy with insulin before maintaining patient on oral hypoglycemic agents. ${ }^{78}$.

Several measures of glycemic control, insulin resistance and pancreatic beta cell function are available. Glycated
e-ISSN 2308-118X

Printed in the Philippines

Copyright (c) 2014 by the JAFES

Received July 16, 2014. Accepted October 21, 2014.

http://dx.doi.org/10.15605/jafes.029.02.11
Corresponding author: Ma. Marylaine Dujunco, MD

Department of Internal Medicine

St. Luke's Medical Center

\#279 E. Rodriguez Sr. Blvd. Quezon City 1102, Philippines

Tel/Fax No.: +632-7230101

E-mail:marylaine85@gmail.com 
hemoglobin or $\mathrm{HbA} 1 \mathrm{c}$ is a form of hemoglobin commonly used to measure the average plasma glucose concentration for 120 days - the life of the red blood cell.

The homeostatic model assessment (HOMA) first described by Matthews, et al., in 1985, is used to quantify beta cell function (HOMA-B) and insulin resistance (HOMA-IR). HOMA is a widely validated clinical and epidemiological tool and is derived from a mathematical assessment of the balance between hepatic glucose output and insulin secretion from insulin and fasting glucose levels. It only requires a single measurement of insulin and glucose in the basal state. HOMA-IR is the product of basal glucose and insulin levels divided by 22.5 and is a simple, inexpensive, and reliable surrogate measure of insulin resistance. HOMA-B, computed as the product of 20 and basal insulin levels divided by the value of basal glucose concentrations minus 3.5, has been proposed to be a good measure of $\beta$-cell function. ${ }^{9}$

Insulin is the most effective hypoglycemic agent known. Early insulin therapy had shown good outcomes on both short-term and long-term glycemic control. ${ }^{7}$ Rapid reduction of glucotoxicity can immediately improve $\beta$-cell function and would preserve its ability to secrete insulin. Hence, glycemic improvement would lead to longer periods of good glycemic control or even remission and could even prevent the development of complications. ${ }^{10}$

Randomized controlled trials have been done to evaluate the benefits of initiating therapy on newly diagnosed diabetics with insulin versus oral hypoglycemic agents. ${ }^{13-18}$ However, no conclusive evidence were available to verify this hypothesis.

The objective of this study is to evaluate the effectiveness of initial insulin therapy versus oral hypoglycemic agents in terms of glucose control, pancreatic beta cell function and adverse effects such as hypoglycemia and weight gain.

\section{METHODOLOGY}

Trials were identified by searching PubMed (June 2012), EMBASE (June 2012), Cochrane Library, Science Direct and Clinical Trials.gov. Search terms using medical subject headings $(\mathrm{MeSH})$ were the following: diabetes mellitus type 2, insulin, oral hypoglycemic agent, randomized controlled trial. Manual search was done at St. Luke's College of Medicine Library. Articles published in any language were considered. Abstracts of the articles selected from each of these multiple searches were reviewed and those which met the inclusion criteria were retrieved for the meta-analysis. Search was also done using Google Scholar and other search engines for additional articles that may be included in this study. Inclusion criteria were as follows: studies of randomized controlled trial which have newly diagnosed type 2 diabetic adults as subjects given insulin with or without metformin versus oral hypoglycemic agent or agents; with the following outcomes: glycemic control (HbA1c), measures of insulin resistance or beta cell function, weight, or episodes of hypoglycemia. Studies with subjects with $\mathrm{HbA} 1 \mathrm{c}>10 \%$, diabetic emergency or any serious comorbid conditions were excluded.

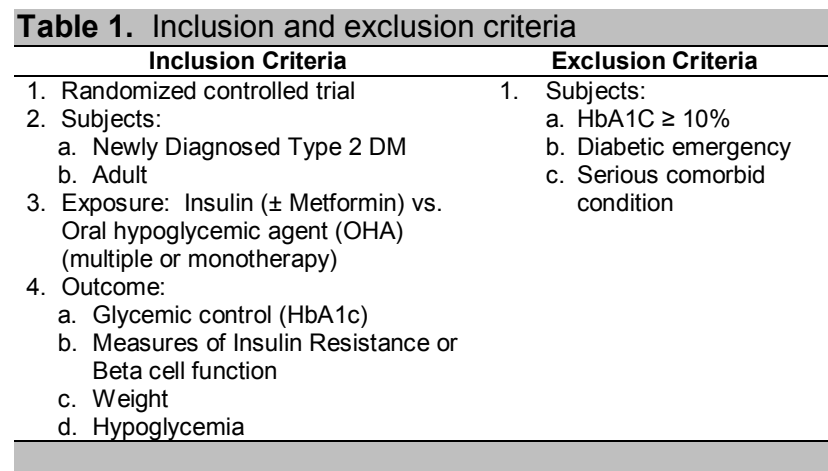

A total of 2618 articles were found by searching five databases and by cross-referencing relevant studies from bibliographies (Figure 1). Fifty-two articles were excluded because these were duplicate articles and an additional 2537 articles were excluded because these studies failed to fulfill the selection criteria. The selection process yielded 29 related articles using insulin as the initiation therapy for newly-diagnosed diabetes mellitus type 2 . These articles were retrieved and their abstracts reviewed and appraised by two independent persons to check for validity. Any incompatibility or question was addressed by a third person.

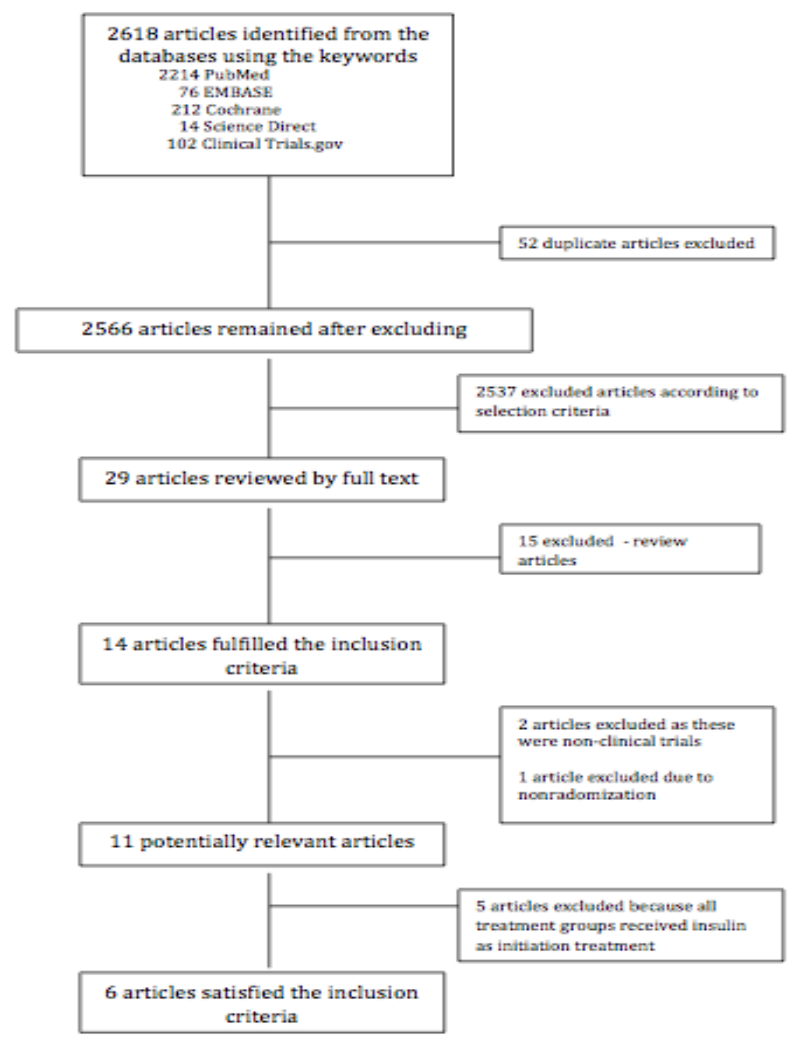

Figure 1. Search strategy for the identification of relevant articles. 
Out of the 29 articles, 15 were excluded since they were review articles. Fourteen articles were left from the initial screening. Two of these articles were again excluded as these were non-clinical trials. One article was excluded since randomization was not done. We were left with eleven potentially relevant articles and these were retrieved, reviewed in full text and assessed. Out of the 11 articles, 5 were excluded as these articles compared two different types of insulin as initial therapy for newlydiagnosed type 2 diabetes mellitus. Of the remaining studies, six out of the eleven potential articles satisfied the inclusion criteria for this meta-analysis.

Table 2. List of excluded studies and reason for exclusion

\begin{tabular}{|c|c|c|}
\hline TITLE & AUTHORS & Reason for Exclusion \\
\hline $\begin{array}{l}\text { Glycemic Response and Attainment of A1c Goals Following } \\
\text { Newly Initiated Insulin Therapy for Type } 2 \text { Diabetes }\end{array}$ & $\begin{array}{l}\text { Nichols, Gregory, et. al. } \\
\text { (2011) }\end{array}$ & Study design was prospective cohort \\
\hline $\begin{array}{c}\text { The Effect of Early Insulin Therapy on Pancreatic B-cell } \\
\text { Function and Long-Term Glycemic Control in Newly } \\
\text { Diagnosed Type } 2 \text { Diabetic Patients }\end{array}$ & $\begin{array}{l}\text { Chon, Suk, et. al. } \\
\qquad(2010)\end{array}$ & Study design was retrospective cohort \\
\hline $\begin{array}{l}\text { Targeting B-cell Function Early in the Course of Therapy for } \\
\text { Type } 2 \text { Diabetes Mellitus }\end{array}$ & $\begin{array}{l}\text { Leahy, Jack L., et. al } \\
\qquad(2010)\end{array}$ & $\begin{array}{c}\text { Examined current perspectives regarding likely mechanisms } \\
\text { of B-cell failure in type } 2 \text { diabetes and their clinical } \\
\text { implications for protecting or sparing B-cells early in the } \\
\text { disease progression }\end{array}$ \\
\hline $\begin{array}{l}\text { Comparison of Gliclazide with Insulin as Initial Treatment } \\
\text { Modality in Newly Diagnosed Type } 2 \text { Diabetes }\end{array}$ & $\begin{array}{l}\text { Chandra, Satish T., et. al. } \\
\text { (2008) }\end{array}$ & $\begin{array}{c}\text { Study was not randomized. The type of treatment the } \\
\text { subjects received were left to their discretion. Quality } \\
\text { assessment score of } C \text { (poor quality) }\end{array}$ \\
\hline $\begin{array}{c}\text { Comparison of Glycemic Control in Patients with Type } 2 \text { on } \\
\text { Basal Insulin and Fixed Combination Oral } \\
\text { AntidiabeticTreatment: Results of a Pilot Study }\end{array}$ & $\begin{array}{l}\text { G. De Mattia, et. al. } \\
\text { (2009) }\end{array}$ & $\begin{array}{c}\text { Compared the coefficient of variance of fasting and post } \\
\text { prandial blood glucose of Type } 2 \text { DM subjects treated with } \\
\text { insulin glargine (Glargine) versus neutral protamine } \\
\text { Hagedorn (NPH) insulin }\end{array}$ \\
\hline $\begin{array}{l}\text { Introducing a Simplified Approach to Insulin Therapy in } \\
\text { Type } 2 \text { Diabetes: a Comparison of Two Single-Dose } \\
\text { Regimens of Insulin Glulisine plus Insulin Glargine and Oral } \\
\text { Antidiabetic Drugs }\end{array}$ & $\begin{array}{l}\text { M.R. Lankisch, et. al. } \\
\text { (2009) }\end{array}$ & $\begin{array}{c}\text { Compared hypoglycemic effect of the addition of a single } \\
\text { bolus of insulin glulisine in combination with basal insulin } \\
\text { glargine and oral antidiabetic drugs }\end{array}$ \\
\hline $\begin{array}{l}\text { Non-inferiority Effects on Glycemic Control and B-cell } \\
\text { Function Improvement in Newly Diagnosed Type } 2 \\
\text { Diabetes Patients: Basal Insulin Monotherapy Versus }\end{array}$ & $\begin{array}{l}\text { Chen, Harn-Shen } \\
\text { (2008) }\end{array}$ & $\begin{array}{l}\text { Compared the effects of basal insulin monotherapy with } \\
\text { continuous subcutaneous insulin infusion treatment }\end{array}$ \\
\hline
\end{tabular}

Continuous Subcutaneous Insulin Infusion Treatment

Recognition of Fasting or Overall Hyperglycemia When Starting Insulin Treatment in Patients with Type 2 Diabetes in General Practice

Vahatalo, Marrku, et. al. Compared diurnal glucose variation in subjects treated with (2008) insulin only, bedtime insulin with sulphonylurea, bedtime insulin with metformin

Table 3. Quality assessment of included studies

\begin{tabular}{|c|c|c|c|c|c|c|}
\hline Quality Assessment & $\begin{array}{l}\text { B Cell function } \\
\text { after } 3.5 \text { yrs }\end{array}$ & $\begin{array}{c}\text { Short term } \\
\text { intensive } \\
\text { therapy in } \\
\text { newly } \\
\text { diagnosed DM }\end{array}$ & $\begin{array}{l}\text { Effects of Insulin } \\
\text { and oral anti- } \\
\text { diabetic agents on } \\
\text { ylucose metabolism }\end{array}$ & $\begin{array}{l}\text { Glycemic control } \\
\text { with diet, } \\
\text { sulfonylurea, } \\
\text { metformin, or } \\
\text { insulin }\end{array}$ & $\begin{array}{c}\text { Beneficial } \\
\text { effects of insulin }\end{array}$ & $\begin{array}{l}\text { Effect of intensive } \\
\text { insulin therapy on } B \\
\text { cell function }\end{array}$ \\
\hline \multirow{7}{*}{$\begin{array}{c}\text { Randomization } \\
\text { Allocation } \\
\text { Concealment } \\
\text { Blinding } \\
\text { Intention to Treat } \\
\text { Adequacy of Follow-up } \\
\text { Quality Scale } \\
\text { No. of Subjects }\end{array}$} & $\begin{array}{l}\text { Harrison, et al, } \\
2012^{5}\end{array}$ & $\mathrm{Hu}$, et al $2011^{6}$ & $\begin{array}{l}\text { Joya-Galeana, et } \\
\text { al, } 2011^{7}\end{array}$ & $\begin{array}{c}\text { Turner, et al, } \\
1999^{8}\end{array}$ & Chen, et al, $2008^{9}$ & Weng, et al, $2008^{10}$ \\
\hline & Yes & Yes & Yes & Yes & Yes & Yes \\
\hline & Yes & Not stated & Not stated & Yes & Not stated & Yes \\
\hline & No & Not stated & Not stated & Not stated & Not stated & Not stated \\
\hline & Yes & Yes & Yes & Yes & Yes & Not stated \\
\hline & Yes & Not stated & Not stated & Not Stated & Yes & Yes \\
\hline & $\begin{array}{c}\mathrm{B} \\
58\end{array}$ & $\begin{array}{l}\text { B } \\
48\end{array}$ & $\begin{array}{l}\text { B } \\
21\end{array}$ & $\begin{array}{c}\text { B } \\
4075\end{array}$ & $\begin{array}{l}B \\
50\end{array}$ & $\begin{array}{c}\mathrm{B} \\
382\end{array}$ \\
\hline Patient & $\begin{array}{c}21-70 \text { y/o; } \\
\text { diagnosed DM } \\
\text { within previous } 2 \\
\text { months }\end{array}$ & $\begin{array}{c}50.6 \pm 7.9 \text { y/o; bmi } \\
25.7+-3.3, \text { no anti } \\
\text { hyperglycemic } \\
\text { therapy }\end{array}$ & $\begin{array}{c}21 \text { diabetic } \\
\text { Mexican } \\
\text { American with } \\
\text { HbA1c } 7 \%\end{array}$ & $\begin{array}{l}25-65 \text { y/o, newly } \\
\text { diagnosed DM } 2 \text {, } \\
\text { fasting plasma } \\
\text { glucose (FPG) more } \\
\text { than } 108 \text { on } 3 \text { occ, }\end{array}$ & $\begin{array}{l}\text { Newly dx dm } 2 \\
\text { with severe } \\
\text { hyperglycemia }\end{array}$ & $\begin{array}{l}\text { 25-70 y/o newly } \\
\text { diagnosed with DM 2, } \\
\text { treatment naïve with } \\
\text { FBS } 7-16.7 \mathrm{mmol} / \mathrm{L}\end{array}$ \\
\hline Exposure & $\begin{array}{l}\text { Insulin + } \\
\text { metformin vs } \\
\text { triple oral } \\
\text { therapy } \\
\text { (metformin, } \\
\text { glyburide, } \\
\text { pioglitazone) }\end{array}$ & $\begin{array}{c}\text { Continuous sq } \\
\text { insulin infusion; } \\
\text { multiple daily } \\
\text { insulin injection; } \\
\text { OHA }\end{array}$ & $\begin{array}{l}\text { Pioglitazone 15- } \\
45 \mathrm{mg} / \text { day } \pm \\
\text { metformin } \pm \\
\text { glipizide vs } \\
\text { insulin glargine } \\
\text { plus glulisine }\end{array}$ & $\begin{array}{l}\text { Diet alone, } \\
\text { insulin, } \\
\text { sulfonylurea, } \\
\text { metformin }\end{array}$ & $\begin{array}{l}\mathrm{NPH} \text { vs obese } \\
\text { metformin, lean } \\
\text { gliclazide MR }\end{array}$ & $\begin{array}{c}\text { Multiple daily insulin } \\
\text { injection (MDI) with } \\
\text { Novolin R and NPH; } \\
\text { continuous } \\
\text { subcutaneous insulin } \\
\text { infusion (CSII) with } \\
\text { Novo Nordisk; } \\
\text { gliclazide } \pm \text { metformin }\end{array}$ \\
\hline Outcome & $\begin{array}{l}\text { B-cell response } \\
\text { at } 0,6,12,18, \\
3042 \text { months. } \\
\text { Glucose, c } \\
\text { peptide, Total } \\
\text { insulin secretion, } \\
\text { weight }\end{array}$ & $\begin{array}{l}\text { Homeostasis } \\
\text { model } \\
\text { assessment } \\
\text { (HOMA) B and } \\
\text { IR }\end{array}$ & $\begin{array}{l}\text { Fasting blood } \\
\text { glucose; HbA1c, } \\
\text { endogenous } \\
\text { glucose } \\
\text { production }\end{array}$ & $\begin{array}{l}\text { Fasting blood } \\
\text { glucose; HbA1c }\end{array}$ & $\begin{array}{l}\text { A1c change and } \\
\text { proportion of subjects } \\
\text { who reached target } \\
\text { treatment target a1c } \\
\text { less than } 7 \text { and } 6.5 \text { at } \\
6 \text { and } 12 \text { months; } \\
\text { HOMA B; HOMA IR }\end{array}$ & $\begin{array}{l}\text { Time of glycemic } \\
\text { remission and } \\
\text { remission rate at } 1 \\
\text { year; HbA1c, FBS, } 2 \mathrm{~h} \\
\text { post prandial glucose; } \\
\text { lipids, HOMA B; } \\
\text { HOMA IR }\end{array}$ \\
\hline Method & $\begin{array}{l}\text { Randomized open } \\
\text { label clinical trial }\end{array}$ & Randomized trial & Randomized trial & $\begin{array}{l}\text { Randomized } \\
\text { controlled trial }\end{array}$ & $\begin{array}{l}\text { Randomized } \\
\text { controlled trial }\end{array}$ & $\begin{array}{l}\text { Randomized parallel- } \\
\text { group trial }\end{array}$ \\
\hline Duration & 3.5 years & 1 year & 6 months & 9 years & 6 months & 1 year \\
\hline
\end{tabular}




\section{RESULTS AND DISCUSSION}

\section{Glucose Control}

Four studies evaluated the effect of initial insulin treatment on glucose control in term of glycosylated hemoglobin $(\mathrm{HbA} 1 \mathrm{c})$. Of the total of 315 patients analyzed, 176 received insulin while 139 received oral hypoglycemic agents. The studies by Harrison and Chen noted slightly better glycemic control with use of insulin however the studies by Weng and Joya-Galeana showed an opposite result. (See Figure 2.)

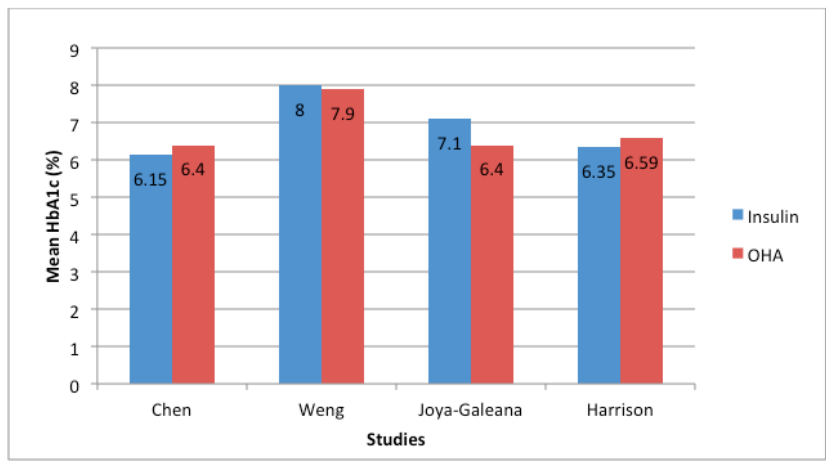

Figure 2. Mean $\mathrm{HbA1c}(\%)$ of subjects treated with insulin vs $\mathrm{OHA}$ in 5 different studies.

Noteworthy is that in both treatment arms, the majority were able to achieve $\mathrm{HbA} 1 \mathrm{c}$ of less than $7 \%$ and a significant number achieved a value of less than $6.5 \%$. These $\mathrm{HbA1c}$ values are the usual treatment goal recommended by clinical guidelines. ${ }^{2,12}$

Figure 3 demonstrates that although there is a trend indicating lower $\mathrm{HbA} 1 \mathrm{c}$ among participants who were given OHAs as initial treatment, the difference between the two groups is not statistically significant. Furthermore, the $\mathrm{Tau}^{2}$ of 0.27 and an $\mathrm{I}^{2}$ of $88 \%$ indicate presence of substantial heterogeneity. Even using the random effects model, this level of heterogeneity remains an issue.

Of the four studies, only Weng did not clearly state intention to treat. A sensitivity analysis was done and Weng's study was excluded from the analysis, however the results as well as the level of heterogeneity remained essentially the same.
Looking at Figure 2, we can see that in studies of Weng, and Joya-Galeana, $\mathrm{HbA} 1 \mathrm{c}$ in the insulin group increased after a year and six months, respectively, however were not statistically significantly different from the oral hypoglycemic agents group ( $p$ value of 0.97 , and 0.92 , respectively).

The relatively short duration of follow up of the included studies may explain the lack of statistically significant difference in $\mathrm{HbA} 1 \mathrm{c}$ between the two study arms. In the study of Turner, 1999-the UKPDS 49-the proportion of patients maintaining target $\mathrm{HbA} 1 \mathrm{c}$ levels declined over the follow-up of 9 years. After 9 years of monotherapy with diet, insulin and sulfonylurea, 9\%, 28\%, and 24\% respectively achieved $\mathrm{HbA} 1 \mathrm{c}$ levels below 7\%. ${ }^{8}$ A study with a longer follow-up is needed in line with the hypothesis that insulin in the early phases of diabetes mellitus type 2 treatment will result in improvement of beta cell function and subsequent better glycemic control in the long term.

\section{Beta Cell Function and Insulin Resistance}

HOMA-Beta reflects the function of pancreatic beta Cells. Two studies reported HOMA-Beta as an outcome. The study by Chen revealed significant improvement in Beta cell function among participants who received initial insulin treatment ${ }^{17}$ however the study by Weng contradicts this result. 9,10

When we analyzed the results from the two studies, the difference between the HOMA-Beta among the two groups is not statistically significant. Likewise, the Tau ${ }^{2}$ of 1951 and an $\mathrm{I}^{2}$ of $91 \%$ indicate presence of substantial heterogeneity. (Figure 4)

The subjects in the study of Chen were newly diagnosed patients with type 2 diabetes mellitus with relatively more severe hyperglycemia despite the fact that they only chose patients with $\mathrm{HbA1c}$ less than $7 \%$. The higher the level of hyperglycemia, the glucotoxicity is worse and theoretically, the greater effect of insulin on HOMA B. Unsurprisingly, the study noted better HOMA B index in the insulin group. ${ }^{17}$

On the effect on insulin resistance, the studies by Weng and Chen showed conflicting results., ${ }^{9} 10$ Weng showed improvement in the insulin resistance among patients in

\begin{tabular}{|c|c|c|c|c|c|c|c|c|c|c|}
\hline \multirow[b]{2}{*}{ Study or Subgroup } & \multicolumn{3}{|c|}{ Insulin } & \multicolumn{3}{|c|}{ Oral Hypoglycemic Agent } & \multicolumn{3}{|c|}{ Mean Difference } & \multirow{2}{*}{$\begin{array}{l}\text { Mean Difference } \\
\text { IV, Random, } 95 \% \mathrm{CI}\end{array}$} \\
\hline & Mean & SD & Total & Mean & SD & Total & Weight & IV, Random, 95\% CI & Year & \\
\hline Weng & 8 & 1.6 & 118 & 7.9 & 1.7 & 101 & $25.8 \%$ & $0.10[-0.34,0.54]$ & 2008 & \\
\hline Chen & 6.15 & 0.51 & 22 & 6.4 & 0.39 & 8 & $27.5 \%$ & $-0.25[-0.59,0.09]$ & 2008 & \\
\hline Joya-Galeana & 7.1 & 0.3 & 12 & 6.4 & 0.2 & 9 & $29.3 \%$ & $0.70[0.49,0.91]$ & 2011 & - \\
\hline Harrison & 6.35 & 0.84 & 24 & 6.59 & 1.94 & 21 & $17.3 \%$ & $-0.24[-1.14,0.66]$ & 2012 & \\
\hline Total $(95 \% \mathrm{Cl})$ & & & 176 & & & 139 & $100.0 \%$ & $0.12[-0.44,0.69]$ & & \\
\hline \multicolumn{7}{|c|}{$\begin{array}{l}\text { Heterogeneity: } \operatorname{Tau}^{2}=0.27 ; \mathrm{Chi}^{2}=24.81, \mathrm{df}=3(\mathrm{P}<0.0001) ; \mathrm{I}^{2}=88 \% \\
\text { Test for overall effect: } \mathrm{Z}=0.42(\mathrm{P}=0.67)\end{array}$} & & & & $\begin{array}{cccc}-4 & -2 & 0 & 1 \\
\text { Favours insulin Favours }\end{array}$ \\
\hline
\end{tabular}

Figure 3. Forest plot comparing the $\mathrm{HbA} 1 \mathrm{c}$ of subjects who received insulin versus $\mathrm{OHA}$ as initial therapy for type 2 DM. 


\begin{tabular}{|c|c|c|c|c|c|c|c|c|c|c|}
\hline \multirow[b]{2}{*}{ Study or Subgroup } & \multicolumn{3}{|c|}{ Insulin } & \multicolumn{3}{|c|}{ Oral Hypoglycemic Agent } & \multicolumn{3}{|c|}{ Mean Difference } & \multirow{2}{*}{$\begin{array}{c}\text { Mean Difference } \\
\mathrm{N} \text {, Random, } 95 \% \mathrm{Cl}\end{array}$} \\
\hline & Mean & SD & Total & Mean & SD & Total & Weight & IV, Random, $95 \% \mathrm{Cl}$ & Year & \\
\hline Weng & 78.9 & 65.2 & 103 & 102.3 & 16 & 90 & $53.5 \%$ & $-23.40[-36.42,-10.38]$ & 2008 & (1) \\
\hline Chen & 111.2 & 66.7 & 22 & 69.1 & 33.5 & 8 & $46.5 \%$ & $42.10[5.83,78.37]$ & 2008 & \\
\hline Total $(95 \% \mathrm{Cl})$ & & & 125 & & & 98 & $100.0 \%$ & $7.07[-56.96,71.11]$ & & \\
\hline $\begin{array}{l}\text { Heterogeneity: Tauª } \\
\text { Test for overall effect }\end{array}$ & $\begin{array}{l}1951.81 \\
Z=0.22\end{array}$ & $\begin{array}{l}1 ; \mathrm{Chi}^{2} \\
(\mathrm{P}=0\end{array}$ & $\begin{array}{l}=11.1 \\
g .83)\end{array}$ & , $d f=1(P$ & 0009 & $91 \%$ & & & & $\begin{array}{lcc}200-100 & 1 & 1 \\
\text { Favours OHA } & 100 & 200 \\
& \text { Favours insulin }\end{array}$ \\
\hline
\end{tabular}

Figure 4. Forest plot comparing HOMA-Beta of subjects treated with insulin versus OHA as initial therapy for type 2 DM.

\begin{tabular}{|c|c|c|c|c|c|c|c|c|c|c|}
\hline \multirow[b]{2}{*}{ Study or Subgroup } & \multicolumn{3}{|c|}{ Insulin } & \multicolumn{3}{|c|}{ Oral Hypoglycemic Agent } & \multicolumn{3}{|c|}{ Mean Difference } & \multirow{2}{*}{$\begin{array}{l}\text { Mean Difference } \\
\text { IV, Random, } 955 \mathrm{Cl}\end{array}$} \\
\hline & Mean & SD & Total & Mean & SD & Total & Weight & IV, Random, $95 \% \mathrm{Cl}$ & Year & \\
\hline Weng & 3.1 & 2.9 & 103 & 4.8 & 4.8 & 90 & $64.6 \%$ & $-1.70[-2.84,-0.56]$ & 2008 & 5 \\
\hline Chen & 4.39 & 2.85 & 22 & 3.95 & 3.23 & 8 & $35.4 \%$ & $0.44-2.10,2.98]$ & 2008 & \\
\hline Total $(95 \% \mathrm{Cl})$ & & & 125 & & & 98 & $100.0 \%$ & $-0.94[-2.95,1.06]$ & & \\
\hline $\begin{array}{l}\text { Heterogeneity: Tauz } \\
\text { Test for overall effect }\end{array}$ & $\begin{array}{l}1.28 ; C \\
z=0.92\end{array}$ & $\begin{array}{l}i^{2}=2 . \\
(P=0\end{array}$ & $\begin{array}{l}\text { 28, } d f= \\
36)\end{array}$ & $1(P=0.13$ & $=56 \%$ & & & & & 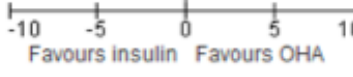 \\
\hline
\end{tabular}

Figure 5. Forest plot comparing the HOMA-IR of subjects treated with insulin versus OHA as initial therapy for type $2 \mathrm{DM}$.

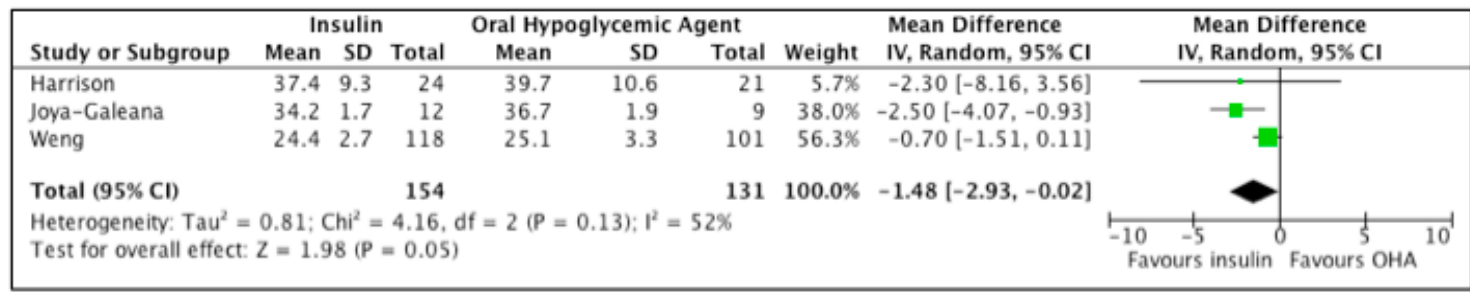

Figure 6. Forest plot comparing the post-treatment BMI of subjects treated with insulin versus OHA as initial therapy for type 2 DM.

the insulin treatment arm, while an opposite finding was seen in the study by Chen.

In terms of insulin resistance as noted by HOMA IR, no significant change from baseline to the end of the intervention and between the insulin groups were noted. However Weng with a greater population of 382 versus 50 in Cheng's study, noted HOMA B was significantly increased in all patients and HOMA IR significantly decreased in all patients with both $\mathrm{p}$ value of $<0.0001 .{ }^{9}$ However when the groups were compared, the difference was not statistically significant.

Analyzing the result further, Figure 5 shows a trend indicating lower HOMA-IR among participants who used insulin. However, the difference between the two groups is not statistically significant. Furthermore, the $\mathrm{Tau}^{2}$ of 1.28 and an $\mathrm{I}^{2}$ of $56 \%$ indicate presence of substantial heterogeneity.

\section{Weight Gain, Hypoglycemia and Other Adverse Effects}

Four studies included post treatment BMI as an outcome. Of the 345 patients analyzed, 184 received insulin while 161 received oral hypoglycemic agents. All four studies showed lower post treatment BMI among participants in the insulin treatment arm. An opposite finding was expected as insulin is known to cause weight gain.
However, other OHA such as sulfonylureas specifically glyburide, glipizide, gliclazide, which were given in the studies of Harrison, Hu, Joya-Galeana, Chen and Weng are also known to cause weight gain. (Figure 6)

Further analysis showed that indeed there is significantly lower post treatment BMI among participants who used insulin. However the $\mathrm{Tau}^{2}$ of 0.81 and an $\mathrm{I}^{2}$ of $52 \%$ indicate presence of heterogeneity. (Figure 8)

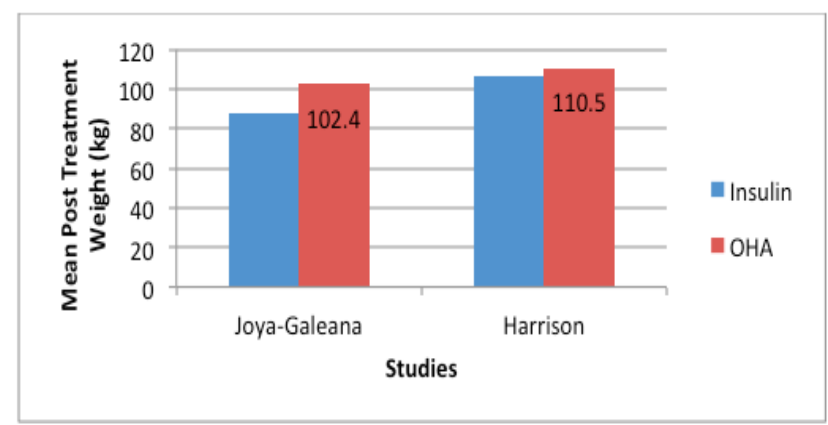

Figure 7. Mean post-treatment weight $(\mathrm{kg})$ of subjects treated with insulin versus $\mathrm{OHA}$ in 3 studies.

Only three studies reported post treatment weight as an outcome. All of the three studies showed a lower weight (however statistically insignificant) among patients who received insulin. 


\begin{tabular}{|c|c|c|c|c|c|c|c|c|c|c|c|}
\hline \multirow[b]{2}{*}{ Study or Subgroup } & \multicolumn{3}{|c|}{ Insulin } & \multicolumn{3}{|c|}{ Oral Hypoglycemic Agent } & \multicolumn{3}{|c|}{ Mean Difference } & \multirow{2}{*}{\multicolumn{2}{|c|}{$\begin{array}{c}\text { Mean Difference } \\
\text { IV, Random, 95\% Cl }\end{array}$}} \\
\hline & Mean & SD & Total & Mean & SD & Total & Weight & IV, Random, 95\% CI & Year & & \\
\hline Joya-Galeana & 88 & 5 & 12 & 102.4 & 5 & 9 & $91.7 \%$ & $-14.40[-18.72,-10.08]$ & 2011 & 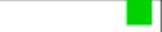 & \\
\hline Harrison & 106.2 & 31.7 & 24 & 110.5 & 31.8 & 21 & $8.3 \%$ & $-4.30[-22.90,14.30]$ & 2012 & & \\
\hline Total $(95 \% \mathrm{CI})$ & & & 36 & & & 30 & $100.0 \%$ & $-13.57[-19.01,-8.12]$ & & $\bullet$ & \\
\hline $\begin{array}{l}\text { Heterogeneity: } \mathrm{Tau}^{2} \\
\text { Test for overall effec }\end{array}$ & $\begin{array}{l}3.56 ; \\
Z=4.8\end{array}$ & $\begin{array}{l}h i^{2}=1 \\
8(P<\end{array}$ & 0.0000 & $=1(\mathrm{P}$ & $1^{2}=$ & & & & & $\begin{array}{l}\text {-100 - } 50 \\
\text { Favours insulin }\end{array}$ & $f_{\text {Favours }}^{50} 100$ \\
\hline
\end{tabular}

Figure 8. Forest plot comparing the post-treatment weight of subjects treated with insulin versus OHA as initial therapy for type 2 DM.

Similar to post treatment BMI, there is a trend of lower post-treatment weight among participants who used insulin, however, the difference between the two groups is not statistically significant.

There were no noted severe hypoglycemic episodes reported in the study of Weng. The proportion of patients with minor hypoglycemic events-prompt recovery after patient self-administered carbohydrate-were also the same in all groups. In the study of Harrison, two subjects in the insulin group had three severe hypoglycemic episodes compared with four subjects with four episodes in the oral hypoglycemic group. Both groups have a comparable number of mild hypoglycemic events, $0.5 \pm$ 0.8 events per month in the insulin group and $0.4 \pm 0.5$ events per month in the oral hypoglycemic group. The hypoglycemic event is affected by the close monitoring of blood sugar, with proper dose adjustment of the intervention.

\section{Issues Regarding Heterogeneity}

A number of factors could have contributed to the heterogeneity (Table 4). Methodological differences such as differences in the interventions as well as different outcome measures and study duration are factors contributing to methodological and statistical heterogeneity. We have anticipated such methodological differences so we used the Random Effects model to analyze this. However, the heterogeneity remains an issue in interpreting the result.

Table 4. Possible sources of heterogeneity

\begin{tabular}{|c|c|}
\hline Type & Possible Sources of Heterogeneity \\
\hline Clinical Heterogeneity & $\begin{array}{l}\text { - Variation in insulin and oral hypoglycemic } \\
\text { agents used } \\
\text { - Different run in period with intervention } \\
\text { - Different primary outcomes }\end{array}$ \\
\hline $\begin{array}{l}\text { Methodological } \\
\text { Heterogeneity }\end{array}$ & - In most studies, blinding was not stated. \\
\hline $\begin{array}{l}\text { Statistical } \\
\text { Heterogeneity }\end{array}$ & $\begin{array}{l}\text { - The primary outcome measures of the } \\
\text { included studies were different. Since } \\
\text { statistical power have been computed for } \\
\text { the primary outcomes, this presents as a } \\
\text { possible source of statistical } \\
\text { heterogeneity. } \\
\text { - Results at the end of the study were used } \\
\text { instead of difference between start and } \\
\text { end of study results. }\end{array}$ \\
\hline
\end{tabular}

\section{Limitations}

In all studies, it was noted that the absolute values were used instead of the mean difference in the laboratory values in the analysis of results. This could have affected the final outcome since the actual change caused by the treatment was not represented. Data were lacking to be able to compare the mean change in terms of $\mathrm{HbA1c}$, HOMA beta, HOMA IR and BMI between the two groups.

\section{CONCLUSION}

Among newly diagnosed type $2 \mathrm{DM}$ patients, there is not enough evidence for or against the use of insulin compared to oral hypoglycemic agent as initial management in terms of improvement in glycemic control, decrease in insulin resistance and improvement in beta cell function..

Heterogeneity of data, short duration of follow-up and lack of clinically relevant outcomes are critical issues that preclude a conclusion on the effectiveness of insulin compared to oral hypoglycemic agents as initial therapy for newly diagnosed diabetes type 2 patients.

There is no clear evidence that insulin offers a clear advantage over oral hypoglycemic agents as initial therapy for newly diagnosed type 2 diabetes mellitus during the first 6 months to 3 years of treatment.

A study of significantly longer duration of follow up of at least 10 years may be needed to establish the long term effects of initial insulin treatment. Likewise, future studies should also include clinical end points such as cardiovascular events and mortality as outcomes of interest and utilize new oral hypoglycemic agents other than sulfonylureas.

\section{References}

1. IDF Diabetes Atlas Sixth Edition, International Diabetes Federation 2013.

2. Garber AJ, et al. AACE Comprehensive Diabetes Management Algorithm. Endocr Pract. 2013;19:327-336.

3. Chang-Chen, KJ, Mullur R, Bernal-Mizrachi E. Beta-cell failure as a complication of diabetes. Rev Endocr Metab Disord. 2008 Dec; 9(4):329-43. http://dx.doi.org/10.1007/s11154-008-9101-5.

4. Age-Adjusted Percentage of Adults with Diabetes Using Diabetes Medication, by Type of Medication, United States, 1997-2011. Centers for Disease Control and Prevention (CDC), National Center for Health Statistics, Division of Health Interview Statistics, data from the National Health Interview Survey. Nov 2013.

5. Shin MS, et al. The Duration of Sulfonylurea Treatment Is Associated with $\beta$-Cell Dysfunction. Diabetes Technol Ther. 2012 Nov;14(11):1033-42. http://dx.doi.org/10.1089/dia.2012.0144.

6. Nathan DM: Initial management of glycemia in type 2 diabetes mellitus. N Engl J Med. 347:1342 -1349, 2002. http://dx.doi.org/ 10.1056/NEJMcp021106. 
7. Ildiko L, et al. Insulin-Based Versus Triple Oral Therapy for Newly Diagnosed Type 2 Diabetes: Which is better? Diabetes Care. October 2009; 32 (10):1789-1795. http://dx.doi.org/10.2337/dc09-0653.

8. Niswender $\mathrm{K}$, et al. Early and Aggressive Initiation of Insulin Therapy for Type 2 Diabetes: What Is the Evidence? Clinical Diabetes. Spring 2009;27(2): 60-68. http://dx.doi.org/10.2337/diaclin.27.2.60.

9. Turner, et al. (1993) Measurement of insulin resistance and $\beta$-cell function: the HOMA and CIGMA approach. Current topics in diabetes research (eds) F. Belfiore, R. Bergman and G. Molinatti Front Diabetes. Basel, Karger. 12: 66-75.

10. Executive Summary: Standards of medical care in diabetes-2010. Diabetes Care. Jan 2010; 33 (Suppl 1): s4-s10. http://dx.doi.org/10.2337/dc10-S004.

11. Prentki M, Nolan CJ. Islet beta cell failure in type 2 diabetes. J Clin Invest. 2006;116:1802-1812. http://dx.doi.org/10.1172/JCI29103.

12. Ryden L, et al. ESC Guidelines on diabetes, pre-diabetes, and cardiovascular diseases developed in collaboration with the EASD. The Task Force on diabetes, pre-diabetes, and cardiovascular diseases of the European Society of Cardiology (ESC) and developed in collaboration with the European Association for the Study of Diabetes (EASD). Eur Heart J. Aug. 2013;34(39):3035-3087. http://dx.doi.org/10.1093/eurheartj/eht108.

13. Harrison LB, et al. Beta-cell function preservation after 3.5 years of intensive diabetes therapy. Diabetes Care. July 2012; 35(7):1406-1412 http://dx.doi.org/10.2337/dc11-2170.
14. $\mathrm{Hu} \mathrm{Y}, \mathrm{Li} \mathrm{L}, \mathrm{Xu} \mathrm{Y}$, et al. Short-term intensive therapy in newly diagnosed type 2 diabetes partially restores both insulin sensitivity and $\beta$-cell function in subjects with long-term remission. Diabetes Care. Aug 2011; 34(8):1848-53. http:/dx/doi.org/10.2337/dc10-2105.

15. Joya-Galeana J, et al. Effects of insulin and oral anti-diabetic agents on glucose metabolism, vascular dysfunction and skeletal muscle inflammation in type 2 diabetic subjects. Diabetes/Metabolism Research and Reviews. 2011; 27(4); 373-382. http://dx.doi.org/ 10.1002/dmrr.1185.

16. Turner RC, et al. Glycemic control with diet, sulfonylurea, metformin, or insulin in patients with type 2 diabetes mellitus: Progressive requirement for multiple therapies (UKPDS 49). JAMA. June 2, 1999; 281(21): 2005-2012. http://dx.doi.org/ 10.1001/jama.281.21.2005

17. Chen HS, et al. Beneficial effects of insulin on glycemic control and beta cell function in newly diagnosed type 2 diabetes with severe hyperglycemia after short term intensive insulin therapy. Diabetes Care. Oct. 2008; 31(10):1927-1932. http://dx.doi.org/10.2337/dco80075 .

18. Weng J, et al. Effect of intensive insulin therapy on beta cell function and glycemic control in patients with newly diagnosed type 2 diabetes: A multicenter randomized parallel-group trial. Lancet. May 24, 2008; 371:1753-1760. http://dx.doi.org/10.1016/S01406736(08)60762-X

Articles and any other material published in the JAFES represent the work of the author(s) and should not be construed to reflect the opinions of the Editors or the Publisher. Authors are required to accomplish, sign and submit scanned copies of the JAFES Declaration: that the article represents original material, that is not being considered for publication or has not been published or accepted for publication elsewhere. Consent forms, as appropriate, have been secured for the publication of information about patients; otherwise, authors declared that all means have been exhausted for securing such consent. The authors have signed disclosures that there are no financial or other relationships that might lead to a conflict of interest. All authors are required to submit Authorship Certifications that the manuscript has been read and approved by all authors, and that the requirements for authorship have been met by each author.

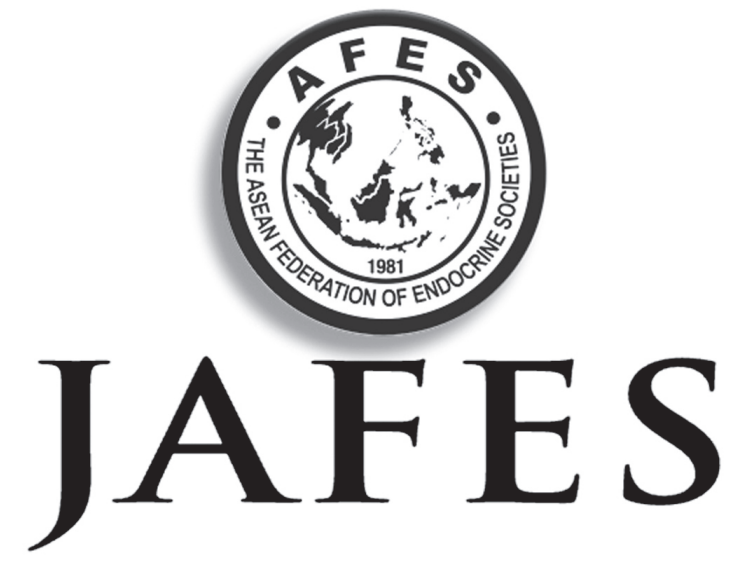

\section{Unique, interesting, enlightening. Your case report and the JAFES.}

